Електронне наукове фахове видання з економічних наук "Modern Economics», №13 (2019), 33-40 https://modecon.mnau.edu.ua | ISSN 2521-6392

УДК 336.74

DOI: https://doi.org/10.31521/modecon.V13(2019)-05

Brychko Maryna, PhD (Economics), Senior Lecturer of the Department of Finance, Banking and Insurance, Sumy State University, Sumy, Ukraine

ORCID ID: 0000-0002-9351-3280

e-mail: m.brychko@uabs.sumdu.edu.ua

Badalov Heorhii, Master of Finance, Banking and Insurance, Sumy State University, Sumy, Ukraine

e-mail: heorhiibadalov@gmail.com

\title{
Trust in Hryvnia: Functional Aspect
}

\begin{abstract}
The purpose of this study is to develop a broader complementary approach to measuring the level of public trust in the Ukrainian national currency - hryvnia. It was suggested to calculate the general level of public trust in hryvnia based on its implementation of the main money functions: unit of account (sometimes referred as a measure of value), medium of exchange, store of value, standard of deferred payment and a world money. This approach allows monitoring the trust of economic agents in hryvnia as the main institution of the financial sector of the economy, as well as determining the causes of the erosion of trust crisis in the national currency (due to violations or inability to fulfil fundamental functions of money). It was found a long-term trend of increasing the general level of public trust in the hryvnia and the monetary system in general. The analysis revealed that from 2008 to 2010 the increase in the general level of trust in hryvnia had been achieved primarily through the performing by the national currency functions of unit of account, standard of deferred payments and the world money. During the period from 2010 to 2013, the source of growth has been an increase trust in hryvnia at the time of its performing function of a store of value. In 2014 there was the shar pest drop in $18 \%$ caused by an inability to fulfill its functions of unit of account, medium of exchange, store of value and the world money Keywords: trust; hryvnia; currency; monetary unit; monetary system.
\end{abstract}

JEL Classification: G21; E31; E40; G41 (1-5).

Бричко М. М., кандидат економічних наук, старший викладач кафедри фінансів, банківської справи та страхування, Сумський державний університет, м. Суми, Україна

Бадалов Г. Р., магістр з фінансів, банківської справи і страхування, Сумський державний університет, м. Суми, Україна

\section{Довіра до гривні: функціональний аспект}

Анотація. В умовах кризових явищ в економіці, що спостерігаються протягом останніх років, знизився рівень довіри до грошово-кредитної системи України. Проявом цього стало стрімке зростання курсу іноземних валют. Наслідком нестабільності національної валюти став масовий обмін гривні на іноземну валюту населенням та загальної доларизації економіки, що призвело до прискорення знецінення гривні. Це, у свою чергу, сприяло ще більшому падінню довіри - як до гривні, так і до грошово-кредитної системи загалом. Недовіра до національної грошової одиниці проявляється у заміщенні найсильнішою іноземною валютою основних функцій грошей: засобу обігу, заощадження та міри вартості. Національна та іноземна валюта, циркулюючи паралельно на фінансовому ринку та на ринку фінансових послуг, починають конкурувати між собою $і$, як результат, сильніша валюта починає витісняти менш цінну при виконанні нею функцій грошей.

Метою статті є розробка інтегрального показника суспільної довіри до національної грошової одиниці $з$ точки зору виконання нею функцій грошей.

Основний результат роботи полягає у розробці науково-методичного підходу до оцінювання рівня суспільної довіри до вітчизняної грошової одиниці шляхом обчислення інтегрального показника на основі врахування виконання гривнею основних функцій: міра вартості, засіб обігу, засіб заощадження, засіб платежу, світові гроші. Такий підхід дозволяє проводити моніторинг довіри економічних агентів до гривні як основного інституту фінансового сектору економіки, а також визначати причини ерозії кризи довіри до національної валюти (внаслідок невиконання нею основних функцій). На основі проведеного дослідження можна стверджувати про існування довгострокового тренду зростання рівня довіри до гривні та грошово-кредитної системи в цілому. Так, з 2008 по 2010 рік відбувалося зростання рівня довіри до гривні за рахунок виконання нею функцій міри

Стаття надійшла до редакції: 09.01.2019

Received: 09 January 2019

Статтю підготовлено в рамках виконання науково-дослідної роботи молодих науковців на тему «Економікоматематичне моделювання механізму відновлення суспільної довіри до фінансового сектору: запорука економічної безпеки України» (номер держ. реєстрації 0117U003924) 
вартості, засобу платежу. У період з 2010 року по 2013 рік зростання прискорилось завдяки виконанням гривнею функції засобу заощаджень, що було обумовлено стабілізацією гривні та збільшенням відсоткових ставок за депозитами у національній валюті. Найбільше падіння рівня довіри до гривні було зафіксовано у 2014 році як реакція економічних агентів на турбулентність фінансового та економічного сектору економіки. Падіння рівня довіри до гривні відбувалося за рахунок не виконання нею функції світових грошей, засобу заощаджень, засобу обігу та міри вартості. Причинами цього були політична та економічна кризи, що призвели до панічних настроїв в суспільстві, стрімке зростання рівня інфляції. Відновлення рівня довіри до національної грошової одиниці у 2015 році стало можливим завдяки зниженню рівня інфляції та стабілізації гривні.

Довіра до банківських установ - це надзвичайно важливий чинник їх діяльності та розвитку. Позитивно на довіру до банківської установи та до грошово-кредитної системи в цілому впливає стабільність національної грошової одиниці. Саме тому з метою дослідження впливу довіри до гривні на основні параметри діяльності банківських установ була розроблена модель інтегрального коефіцієнта довіри на основі функцій гривні. Наслідком відновлення цього виду довіри є стабілізація ресурсної бази та нормалізація банківського бізнесу.

Ключові слова: довіра; гривня; валюта; грошова одиниця; монетарна система.

Problem statement. In the conditions of the crisis phenomena in the economy, that are observed in recent years, the level of trust in the monetary system of Ukraine has decreased. The manifestation of this was the rapid growth of the foreign exchange rate. The result of the volatility of the national currency was the massive exchange of Hryvnia against foreign currency by the Ukrainian consumers and the general dollarization of the economy, which led to acceleration of depreciation of the national currency Hryvnia. This process was accompanied by outflow of deposits from banking institutions. It contributed to an even greater fall of trust, both in the national currency (Hryvnia) and in the monetary system in general. Distrust of the national currency is manifested in replacing by the most powerful foreign currency the main functions of money - medium of exchange, a store of value and a measure of value. National and foreign currency, circulating simultaneously in the financial market and in the financial services market, begin to compete with each other, and as a result, a stronger currency (foreign currency) starts to crowd out less valuable (the Ukrainian Hryvnia) when it performs its functions of money.

Analysis of the recent research and publications. To date, foreign and domestic scientific literature raises the question of the trust importance in the monetary system. Existing scientific and methodological approaches to revealing the dynamics of public trust are divided into the following two groups: qualitative (based on survey) and quantitative (based on different groups of indicators) methodologies of trust assessment. Qualitative methodologies of trust assessment are grounded on obtaining primary sociological information, based on oral or written appeal to the studied group of people with issues whose content is the problem of research at the empirical level. To date, there are many international and national surveys of economic agents about their trust/mistrust in individual financial institutions (banks), the National bank of Ukraine (NBU), public authorities, indices of optimism/pessimism, private indices (World Value Survey [1], General Social Survey [2], Eurobarometer [3], European Social Survey [4], Consumer Confidence Index [5], GfK Trust Index [6], etc.). The data obtained by the survey method does not always differ in the continuity and stability of the sample, which makes it difficult to use them for comprehensive assessment of the dynamics of public trust. However, the very nature of questioning methods can reflect the conventional nature of trust as the sum of certain expectations and subjective thoughts.

Quantitative methodologies of trust assessment are based on the use of a set of indicators, or estimated indices $[7,8,9,10]$. The multi-factor index allows using a wide range of economic statistics to assess trust. A disadvantage is subjectivity in assessing the weight of the indicators and a sampling of indicators. The use of the indicators of both groups (in the presence of available data) reveals the peculiarities of the formation and accumulation of trust in post-soviet economies. It is necessary to take into account the significant differences in the relationship of trust and economic policy in these countries, caused by the peculiarities of the institutional environment, achieved level of development, etc..

The purpose of the article is to develop an integral indicator of public trust in the national currency in terms of fulfilling its functions of money.

Presentation of the main research material. Trust in the national currency is proposed to be viewed as a form of public trust at the institutional level that reflects the attitude of economic agents to the main institution of the financial sector of the economy, based on the idea or knowledge of the principles and mechanisms of the functioning of the money and is related to the possibility of constructing forecasts for the possible change of the national currency (relative to other currencies), confidence, or the expectation that the national currency will fulfill all the functions of money.

The approbation of the scientific and methodical approach to determining the level of trust of economic agents in the national currency is made for the Ukrainian currency - Hryvnia. According to the major functions of money, trust in Hryvnia can be divided into the following five indicators: unit of account, medium of exchange, store of value, standard of deferred payment and a world money.

Trust in hryvnia as a unit of account (sometimes referred as a measure of value). Hryvnia as a unit of account and a standard of measurement provide a 
common measure of value of goods and services being exchanged. Hryvnia is used to measure and to record prices, financial transactions, etc. Thus, price stability reflects the maintenance of the purchasing power of the national currency on the basis of maintaining low, stable rates of inflation in the medium term. That is why, in order to reflect trust in hryvnia as a result its performance of the unit of account function, the the inflation index expressed by the consumer price index could be used. For the purpose of correct inperpretation of the results obtained it should be noted that the level of trust in the hryvnia and the consumer price index are in inverse relationship - the increase of inflation leads to a decrease in public trust in hryvnia.

Indicator of trust in hryvnia as a unit of account for the period 2008-2017 are presented in Figure 1.

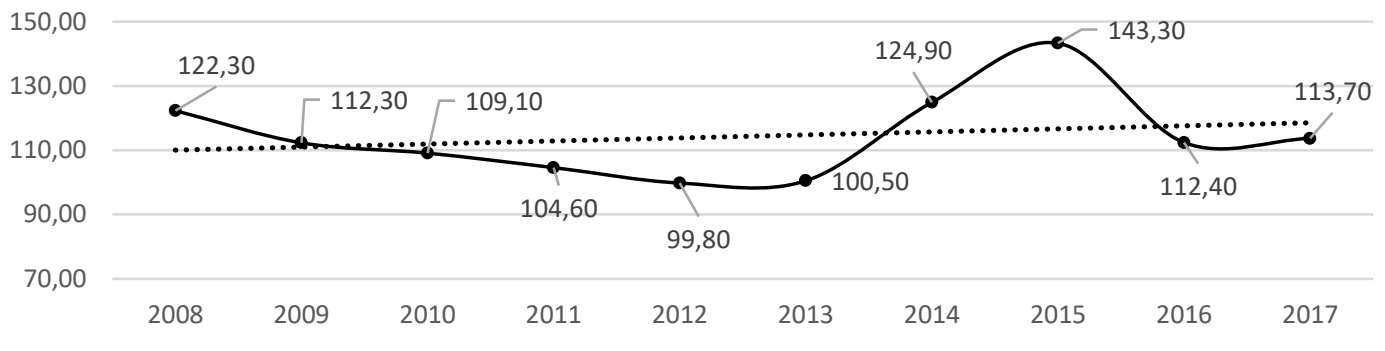

Figure 1 - Dynamics of the measured trust in hryvnia as a unit of account during the period 2008-2017

Source: submitted by the authors

The data presented in Figure 1 shows a steady tendency to reduce the inflation rate from the crisis of 2008 to 2012. Thus, the consumer price index for the whole analyzed period reached its minimum value of $99.8 \%$ in 2012, which may be explained by a certain stabilization of economic processes in the country. However, the political change in the ruling regime, the negative events in the East of Ukraine, the annexation of the Autonomous Republic of Crimea, and the conduct of the anti-terrorist operation amplified the panic expectations in society, prompting the growth of inflation, which in 2015 reached its record high of $143.3 \%$ over the past 10 years.

By implementing a weighted monetary policy and stabilizing the financial sector of the economy, since 2016, inflation has fallen to the level of 2009. In 2017, there were further minor variations (113.7\%). Taking into account the inverse relationship between trust and the consumer price index, in 2012 trust in hryvnia reached its maximum level. The year 2015 was characterized by a crisis of trust in the national currency.

Trust in hryvnia as a medium of exchange. This function of money consists of the money ability to be an intermediary in the exchange of Goods-Money-Goods to facilitate transactions. Economic agents often use foreign currency as a method of payment in the markets for goods, services, labor, and financial capital.There is a large part of economic agents who have a low level of trust in the banking system at all and hryvnia in particular, thus keep funds in foreign currency at home in the form of savings.
In some cases, economic agents exchange hryvnias to US dollars, and then, when the time came, exchange them again to the national currency in order to use them in payments. However, the majority pay by the foreign currency, especially in private purchase and sale transactions (secondary real estate, cars, etc.). Therefore, the following indicator could measure the level of public trust in the hryvnia as a medium of exchange:

$$
T_{m e}^{U A H}=\frac{\mathrm{M}_{0}}{\mathrm{M}_{0}+\mathrm{C}} \times 100 \%
$$

where $T_{m e}^{U A H}$ - the level of public trust in hryvnia as a medium of exchange; hryvnias;

$$
\text { Mo - material currency (cash itself), thousand }
$$

C - foreign currency in cash converted into hryvnia by the current exchange rate indicator, thousand hryvnias.

According to the model, the higher the level of cash in hryvnia compared to cash in the form of foreign currency is, the greater the trust in the national currency is. In other words, formula (1) characterizes the ratio of cash in hryvnia and cash in the form of foreign currency. The positive dynamics of the indicator increasing testifies to the increase of hryvnia cash in the total volume of cash, and, accordingly, reflects the growth of trust in the national currency.

Indicator of trust in the hryvnia as a medium of exchange for the period 2008-2017 is presented in Figure 2. 


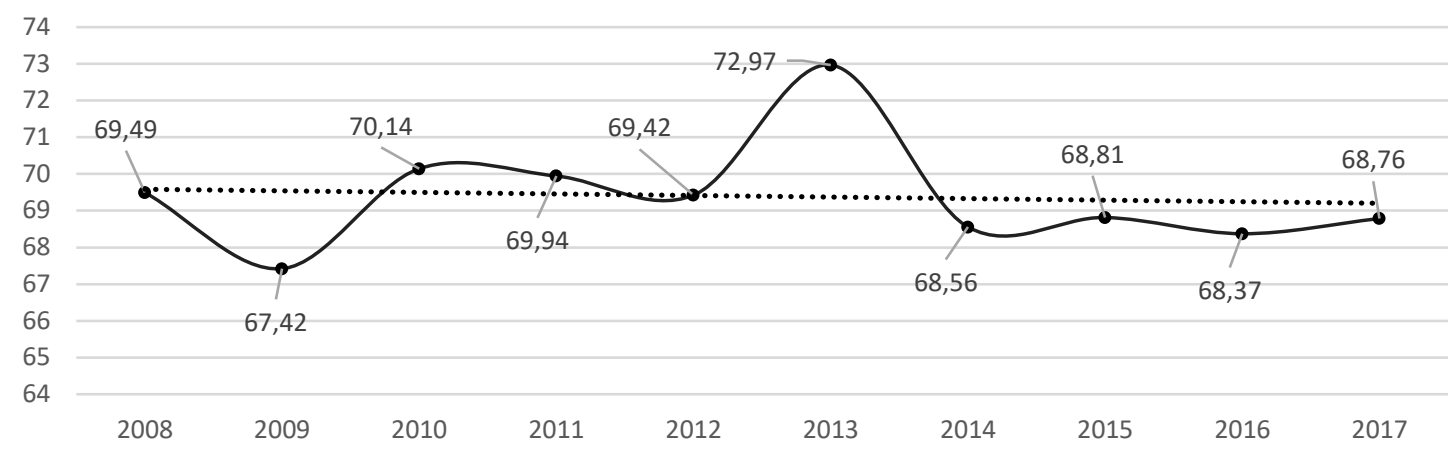

Figure 2 - Dynamics of the measured trust in hryvnia as a medium of exchange during the period 2008-2017

Source: submitted by the authors

As seen from Figure 2, there is no long-term trend of increasing or decreasing in trust in hryvnia as a medium of exchange during the period 2008-2017. As shown above, during 2009-2010 there was a tendency of increasing trust indicator. However, during 2010-2012 trust in hryvnia as a medium of exchange decreased slightly and ranged between 69.42 and 70.14. In 2013, trust in hryvnia as a medium of exchange reached the maximum value (72.97\%) for the analyzing period. This could be explained by economic stabilization in the whole and and the exchange rate of the national currency in particular, which allowed consumers to sell foreign currency in cash that accordingly increased cash in the form of hryvnia in the economy of the country. However, the political instability in 2014, military actions on the territory of Ukraine led to a decrease of GDP and a sharp increase of hryvnia exchange rate that accordingly caused a sharp fall in the level of trust in hryvnia as a medium of exchange in 2014. The economic stabilization and structural reform programme, starting in 2015 , has led to slightly restoring trust in hryvnia as a medium of exchange. However, trust have not reached even the level of 2008 that could indicate the destructive processes in economic agent's expectations about future developments.

Trust in hryvnia as a store of value. Holding money can be viewed as the most convenient way to keep a reserve of liquid assets that can be retained over time (it will still hold its value the next day, or the next year). Comparing to real estate, gold, and other tangible assets, bank deposits is a much easier way of storing value because they can be easily converted into other things in order to fund spending or exchanges at a later day. However, this function of money may not be perfectly accurate in reality. Since money loses some of its value due to inflation, but it remains money.

Under normal curcumstances, economic agents are willing to keep a part of their wealth in form of money (short-term bank deposits, cash and/or cash equivalents). In economic literature, this phemonen is known as liquidity preference. However, the bigger part of wealth is kept in form of money, the greater trust in hryvnia is formed.

Therefore, the following indicator could measure the level of public trust in the hryvnia as a store of value:

$$
T_{S v}^{U A H}=\frac{D^{U A H}+S^{U A H}}{\left(\mathrm{M}_{3}-\mathrm{M}_{1}\right)+\mathrm{C}} \times 100 \%
$$

where $T_{s v}^{U A H}$ - the level of public trust in the hryvnia as a store of value in \%;

$D^{U A H}$ - the value of term deposits in hryvnia, thousand hryvnias;

$S^{U A H}$ - the value of the securities that are included in the aggregate $M_{3}$ and are issued in hryvnias, thousand hryvnias; hryvnias;

$M_{1}, M_{3}$ - monetary aggregates, thousand

$\mathrm{C}$ - foreign currency in cash in Ukraine converted into hryvnia equivalent by the current exchange rate indicator, thousand hryvnias.

In other words, formula 2 describes the share of the amount of time deposits in the national currency and securities in national currency in the amount of all time deposits and securities in Ukraine. The positive dynamics of the increase of this indicator in time testifies to an increase in the share of economic agents deposits in hryvnia in the total amount of savings of the population, and, accordingly, shows the growth of trust in the national currency. According to this formula, the larger the amount of term deposits in hryvnia and securities are, the greater the trust in the Ukrainian national currency is.

Calculated values of the indicator of trust in the hryvnia as a store of value for the period 2008-2017 is depicted in Figure 3. 


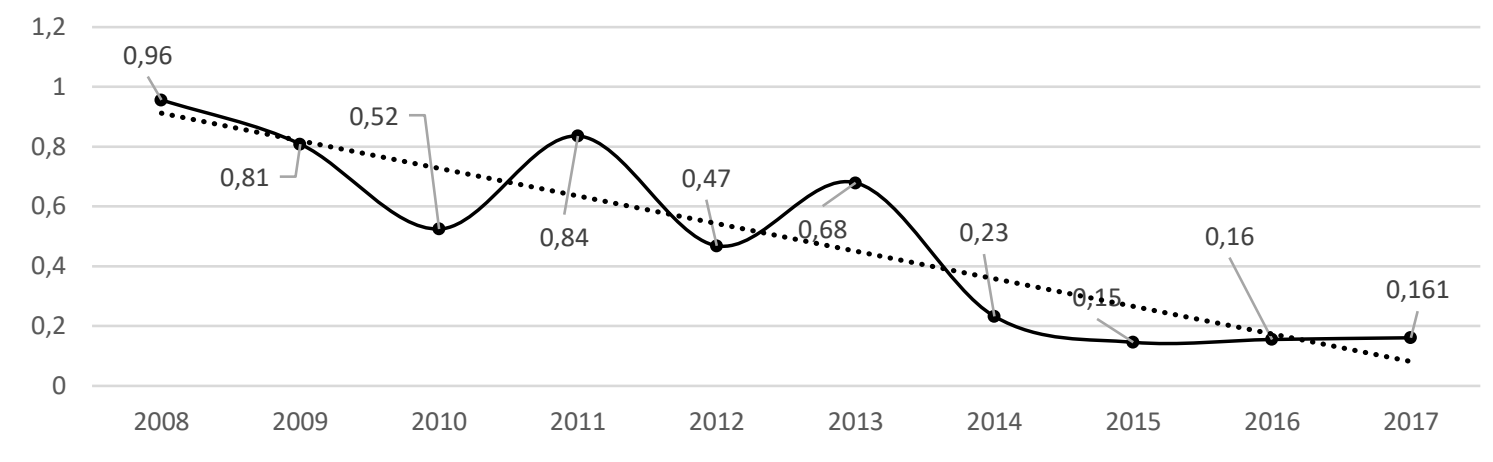

Figure 3 - Dynamics of the measured trust in hryvnia as a store of value during the period 2008-2017

Source: submitted by the authors

Based on the data presented in the figure above it could be argued that trust in hryvnia as a store of value is characterized by high volatility during analysed years 2008-2017. Between crisis 2008 to recovering 2010 years, the negative tendency to decrease in indicator of trust in hryvnia as a store of value could be observed. As of 2010, the indicator was 54 per cent lower than in 2008. This could be due to consequences of the global financial crisis that led to economic instability in the subsequent years. Accordingly, disbalances that took place in the financial market resulted in economic agents preferences to keep funds in foreign currency. As a result, the growth of the foreign currency deposits was amounted to USD 13.87 billion. However, in 2011, the trust indicator recorded growth totaling $59 \%$ compared to the previous year's period. This could be attributed to several factors, such as stabilizing the Ukrainian national currency and increase in interest rates on deposits in hryvnia. As early as 2012, however, the trust in hryvnia as a store of value decreased due to lower interest rates on deposits in the national currency, that in 2011 were artificially inflated to overcome the hryvnia deficit in banks. The situation stabilized in 2013, but the level of trust in hryvnia as a store of value has remained below the level recorded in 2011. Since 2014, there has been a decrease in the level of trust in hryvnia as a store of value. Evidence suggests that reasons for this are included general economic instability in Ukraine and a sharp decrease in the hryvnia exchange rate. Data collected in 2014-207 show that economic agent's prefered foreign currency in order to protect their savings from potential risks.

Trust in hryvnia as a standard of deferred payment. This function of money consists in the ability of hryvnia to serve the repayment of various debt obligations between the subjects of economic relations that arise in the process of expanded reproduction. When hryvnia is used as a medium of exchange with oportunity to spread payments over a period of time, it forms the basis for credit transactions. In a modern economy, most transactions (buying and selling) are related to the use of credit cards. Therefore, trust in hryvnia as a standard of deferred payment expressed as a share of cashless payments in total card (issued by Ukrainian banks) operations. Trust in hryvnia as a standard of deferred payment for the period $2008-2017$ is summarized in the figure 4 below.

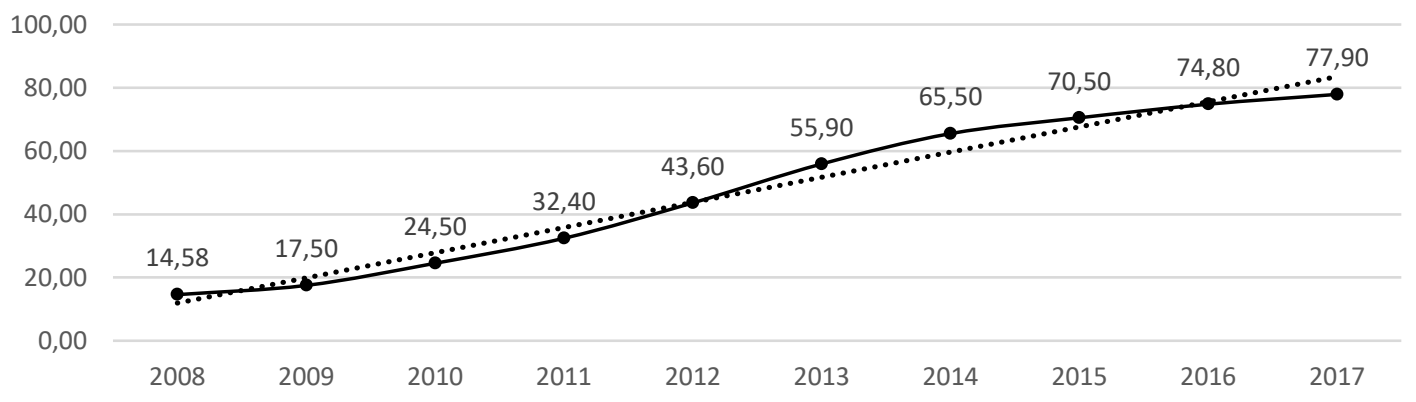

Figure 4 - Dynamics of the measured trust in hryvnia as a standard of deferred payment during the period 2008-2017

Source: submitted by the authors

The data presented in Figure 4 shows a steady tendency of increasing in the share of non-cash transactions in the total volume of transactions using payment cards issued by Ukrainian banks for the entire 
period of analysis. Ukrainians are increasingly pay with hryvnia through credit cards, as they are more convenient and safer than cash payments. A further dynamic influence were expanding the payment infrastructure (the rapid growth of the ATM network, the network of retail POS-terminals) and fasilitation innovation technologies (such as as Apple Pay and Google Pay) that allows economic agents to complete credit transactions (the repayment of money loaned or loan commitment made, or payment for goods, services etc.) without help of a branch representative or teller. As of beginning of October 2018, there were 6.7 POS-terminals per 1,000 inhabitants in Ukraine (NBU). In addition, there is an expansion of the list of payments that can be made using credit cards.

Trust in hryvnia as a world money. World money is a function in which money serves the movement of value in international economic circulation and provides realization of mutual relations between countries. The following means that in order implementing the function word money hryvnia shoul be used in the payments for foreign trade operations, granting of loans and other agreements. Hryvnia is not fully convertible currency; payments in the Ukrainian hryvnia are not made on international transactions and the exchange rate is not determined on the world currency market. The above mentioned indicates that hryvnia cannot carry out this function fully. However, taking into account high volatility of the hryvnia exchange rate against foreign currencies and connected to it bank panic and bank run, it is necessary to include official exchange rate of Hryvnia against US dollar into investigation.

It should be noted that the level of trust in the hryvnia has an inverse relationship with volatility of Hryvnia exchange rate against US Dollar. The plunge in the value of the hryvnia leads to a decrease in public trust in the national currency, and vice versa (Figure 5).

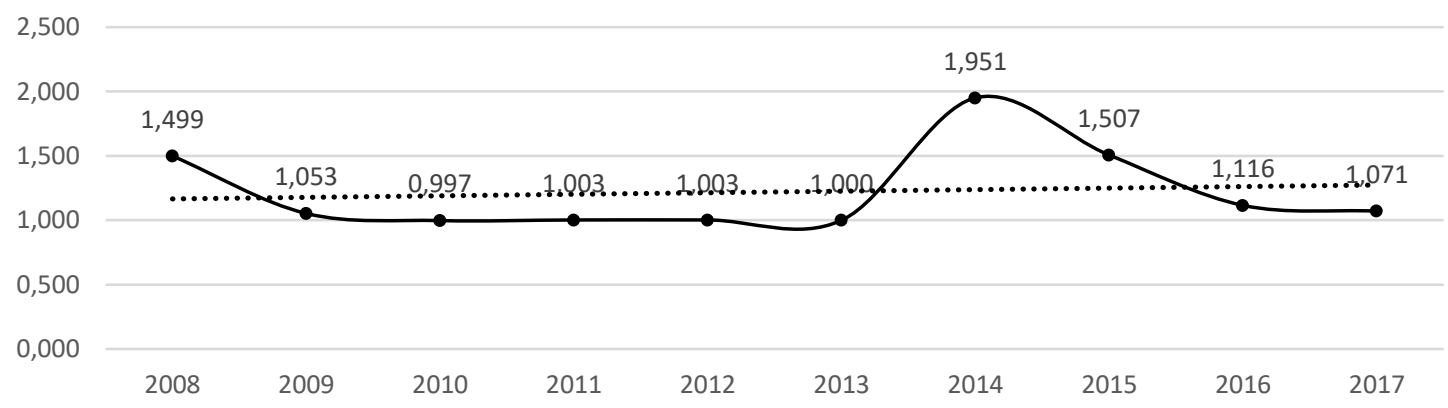

Figure 5 - Dynamics of the measured trust in hryvnia as a world money during the period 2008-2017

Source: submitted by the authors

The information provided in the Figure 5 indicates two trust crisis int the Ukrainian national currency towards US Dollar. The first crisis is connected with the global financial crisis of 2008 and was accompanied by a decrease in the Ukrainian GDP and rising inflation. The central bank was unable to deal with such shocks and has not taken any actions to support the hryvnia, despite the availability of about $\$ 35$ billion of foreign exchange reserves at that time that could be used for appropriate currency interventions. The next trust crisis was in 2014. Hostilities in eastern Ukraine resulted in the flight of foreign capital, the decline of exporters' revenues and other problems that deprived the country of foreign currency that led to its deficit. Negative processes that took place in foreign exchange market were reinforced by the low level of gold and foreign exchange reserves that unallowed the NBU to carry out currency interventions to stabilize the national currency. However, starting from 2015, situation has stabilized and almost reached the pre-crisis level in 2017.

A measure of public trust in hryvnia in the fulfilment of functions of money can be calculated as:
$\mathrm{T}_{\mathrm{UAH}}=\mathrm{K} * \mathrm{~W} * \frac{\left(\mathrm{T}_{\mathrm{ua}}^{\mathrm{UAH}}\right)_{\mathrm{t}}}{\left(\mathrm{T}_{\mathrm{ua}}^{\mathrm{UAH}}\right)_{0}}+\mathrm{K} * \mathrm{~W} * \frac{\left(\mathrm{T}_{\mathrm{me}}^{\mathrm{UAH}}\right)_{\mathrm{t}}}{\left(\mathrm{T}_{\mathrm{me}}^{\mathrm{UAH}}\right)_{0}}+\mathrm{K} * \mathrm{~W} *$
$\frac{\left(\mathrm{T}_{\mathrm{sV}}^{\mathrm{UAH}}\right)_{\mathrm{t}}}{\left(\mathrm{T}_{\mathrm{sV}}^{\mathrm{UAH}}\right)_{0}}+\mathrm{K} * \mathrm{~W} * \frac{\left(\mathrm{T}_{\mathrm{sdp}}^{\mathrm{UAH}}\right)_{\mathrm{t}}}{\left.\mathrm{T}_{\mathrm{sdp}}^{\mathrm{UAH}}\right)_{0}}+\mathrm{K} * \mathrm{~W} * \frac{\left(\mathrm{T}_{\mathrm{wm}}^{\mathrm{UAH}}\right)_{\mathrm{t}}}{\left(\mathrm{T}_{\mathrm{wm}}^{\mathrm{UAH}}\right)_{0}}$

where $\quad T_{U A H}$ - general level of public trust in hryvnia; $\mathrm{K}$ - coefficient that shows positive (1) or negative $(-1)$ influence of the trust components (functions of money) on the general level of public trust in hryvnia;

W - weight coefficient;

$T_{u a}^{U A H}$ - trust in hryvnia as a unit of account; $T_{m e}^{U A H}$ - trust in hryvnia as a medium of exchange;

$T_{S v}^{U A H}$ - trust in the hryvnia as a store of value; $T_{s d p}^{U A H}$ - trust in the hryvnia as a standard of deferred payments;

$T_{w m}^{U A H}$ - trust in the hryvnia as the world money.

This means that general level of trust in hryvnia could be decomposed as five functions of money: unit of account, medium of exchange, store of value, standard of deferred payments and the world money. The initial value of each trust indicator in 2008 is equal to $100 \%$. The level of trust could be calculated as a sum of obtained trust measureas as a medium of exchange, store of value, 
standard of deferred payments with the exception of the trust in hryvnia as a unit of account and word of money. The weight of each indicator is equal to 0.2 , since each function has an equal role. Graphical visualization of the obtained data is presented in Figure 6.

Based on the data shown in Figure 6, it can be argued that there is a long-term trend of increasing the general level of public trust in the hryvnia and the monetary system in general. From 2008 to 2010, there was an increase in the general level of trust in the hryvnia due to increased reliance on the nation currency in performing of unit of account, standard of deferred payments and the world money functions. During the period from 2010 to 2013, the growth accelerated due to the strengthen confidence in hryvnia at the time of its performing a store of value function. This was achieved through economic stabilization and higher interest rates on time deposits in the national currency. However, it can be highlighted the neven growth of public trust in hryvnia. Thus, the amplitude of growth in the level of trust in the hryvnia is not a constant value throughout the analyzed period. The strongest gains are being achieved in 2013 when trust in the national currency have increased by over 53 percentage points in relation to the preceding year.

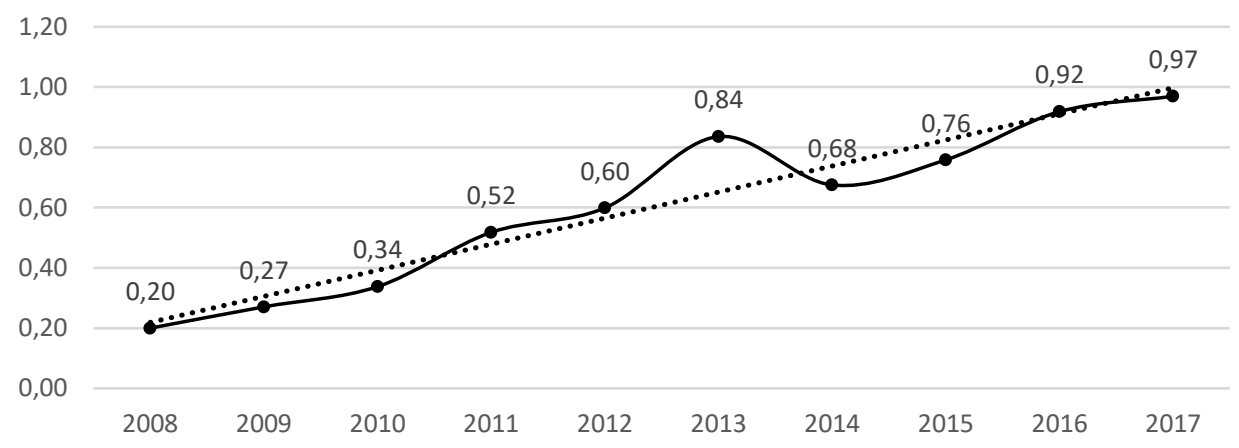

Figure 6 - Dynamics of the level of trust in hryvnia during the period of 2008-2017

Source: submitted by the authors

As seen from the Figure 6, in comparison with previous years, the highest decline in public trust in hryvnia was recorded in 2014 . The sharpest drop in $18 \%$ has been caused by reaction of economic agents to turbulence in the financial and economic sectors of the economy. In 2014, the Ukrainian currency was unable to fulfill its unit of account, medium of exchange, store of value and the world money functions. The reasons for this were the political and economic crises, which led to panic in society, the rapid growth of inflation, and instability of the hryvnia exchange rate.

After decreasing of the public trust in hryvnia in 2014, the National Bank of Ukraine gradually pursued the liberalization of administrative restrictions to stabilize the situation on the monetary and foreign exchange markets. This was aimed at improving the business climate and, at the same time, preserving macro-financial stability. The result was a further stabilization of the situation in the monetary and foreign exchange markets.

Restoration of the level of trust in the national currency in 2016 became possible due to the decreasing of inflation and the stabilization of hryvnia exchange rate. There was also an increase in savings deposits of the population in banks starting in 2016 ( $7 \%$ growth in relation to the preceding year). This was facilitated by an increase in household incomes and an increase in the attractiveness of hryvnia savings deposits against the backdrop of strengthening hryvnia exchange rate. A bright indicator of public trust restoration in hryvnia is the fact that Ukrainians have increased the sale of currency five times.

Summary. In the conditions of the crisis phenomena observed in the economy in recent years, the level of trust in the monetary system of Ukraine has decreased. The manifestation of this was the rapid growth of the foreign exchange rate. As a result of the national currency volatility, the massive exchange of hryvnia against foreign currency by the population, which led to accelerating the depreciation of the hryvnia. This process was accompanied by the outflow of deposits from banking institutions. This, in turn, contributed to an even greater drop in the level of trust, both in hryvnia and in the banking system as a whole. That is, trust in the national currency has a direct impact on the financial stability of the banking system. 


\section{References:}

1. World Values Survey Publications. World Values Survey. Retrieved from http://www.worldvaluessurvey.org/WVSContents.jsp.

2. The General Social Survey. NORC at the University of Chicago. Retrieved from http://www.gss.norc.org.

3. Eurobarometer Public Opinion. European Comission. Retrieved from http://ec.europa.eu/COMMFrontOffice/publicopinion/index.cfm.

4. Data and Documentation. European Social Survey. Retrieved from https://www.europeansocialsurvey.org/data/

5. Consumer confidence index. OECD Data. Retrieved from https://data.oecd.org/leadind/consumer-confidence-index-cci.htm

6. Indeks doveriya po versii GFK. Gumanitarnyye tekhnologii. Retrieved from https://gtmarket.ru/research/gfk-trust-index [in Ukrainian].

7. Hansen, T. (2012). Understanding trust in financial services: the influence of financial healthiness, knowledge, and satisfaction. Journal of Service Research, 15, 280-295. DOI: https://doi.org/10.1177/1094670512439105.

8. Chuanyi, T. (2013). After the global financial crash: individual factors differentiating young adult consumers' trust in banks and financial institutions. Journal of Retailing and Consumer Services, 20, 26-33. DOI: https://doi.org/10.1016/j.jretconser.2012.10.001.

9. Nienaber, A. M. (2013). A meta-analysis and meta-regression of organizational trust in the financial services sector. International Journal of Bank Marketing, 32, 367-407. DOI: https://doi.org/10.1108/IJBM-12-2013-0146.

10. Ferreira, F. A. (2015). A metacognitive decision making based-approach to bank customer loyalty measurement and management. Technological and Economic Development of Economy, 21, 280-300. DOI: https://doi.org/10.3846/20294913.2014.981764. 